\title{
ABCB1 Gene
}

National Cancer Institute

\section{Source}

National Cancer Institute. ABCB1 Gene. NCI Thesaurus. Code C17966.

This gene plays a role in multi-drug resistance and is involved in blood-brain barrier transport. 